\title{
Development of Bio-functional Materials from Agricultural/Forestry Processed Wastes using a Concept of Multi-utilization with Pyrolysis
}

\author{
Han Chien LIN ${ }^{1, *}$, Ying-Pin Huang ${ }^{2}$ \\ ${ }^{1}$ Department of Wood Based Materials and Design, National Chiayi University, Taiwan \\ ${ }^{2}$ Clean Energy and Eco-Technology, TRI South, Taiwan
}

Copyright $\bigcirc 2016$ by authors, all rights reserved. Authors agree that this article remains permanently open access under the terms of the Creative Commons Attribution License 4.0 International License

\begin{abstract}
Pyrolysis of agricultural/forestry processed wastes (AFPW) is one approach that has been investigated to develop materials into products of higher value. This paper describes a concept of multi-utilization with pyrolysis under various conditions which has been extensively prepared for related bio-functional materials like biochar, charcoal and activated carbon (AC). The prepared materials were developed into products such as biochar as part of cultural media for agricultural production; charcoal or $\mathrm{AC}$ as a potential moisture-proof adsorbent for food use; and the $\mathrm{AC}$ as a kind of liquid absorption for water purification. The biochar was prepared from AFPW as a cultural media substrate. Cultural media with biochar can be applied to vegetable plug seedlings with functions including preserving moisture and fertility, offering oxygen to expand the roots. For a food moisture-proof adsorbent, bamboo and wood charcoals were refined into various ACs using physical activations. The hygroscopicity of the resulting AC was better than that of charcoals, and the water activity of the $\mathrm{AC}$ was from 0.45 to 0.46 . In addition, water purifying $\mathrm{AC}$ used sorghum distillery residue with the method of physics activation with steam-activation, which meets the quality standard for drinking water in Taiwan. The above products are concerned with multi-utilization under various pyrolysis conditions which can be used as a reference for resource reutilization from AFPW and also as examples of bio-functional materials' ability to be implemented in a sustainable reuse of resources.
\end{abstract}

Keywords Pyrolysis, Multi-utilization, Agricultural/ Forestry Processed Wastes, Bio-functional Materials

\section{Introduction}

In the last 100 years many problems have come to threaten the environment, such as vanishing forests, acid rain, the burning of fossil-fuels and global warming. Since 2000, anthropogenic carbon dioxide $\left(\mathrm{CO}_{2}\right)$ emissions, unprecedented high levels of greenhouse gases in the atmosphere, have risen by more than 3\% annually, putting earth's ecosystems on a trajectory toward rapid climate change that is both dangerous and irreversible $[1,2]$. Currently, researchers are focusing on so-called "bio-materials" and/or "eco-materials" that make effective and environmentally friendly use of natural resources, such as the reuse of natural wastes, the recycling of industrial wastes, the development of new environmentally friendly materials, etc.

Pyrolysis, one thermochemical process, is generally used for the conversion of biomass into fuels, char (biochar, charcoal and carbon), and by-products in this conversion process [3]. It has been estimated that by the year 2050 about $80 \%$ of all crops and forestry residue may be converted into biochar and energy according to the International Biochar Initiative Organization [4]. Agricultural/forestry processed wastes (AFPW) could be rich resources in the earth [5] and as a precursor for preparing biochar and activated carbon (AC) with various preparation conditions [6].

The advantages of AFPW as the precursor for biochar, charcoal and $\mathrm{AC}$ include solving the problem of wastes, converting it to environment functional materials, decreasing the amount of AFPW and increasing it with a higher value-added. The different preparations of AFPW can be adapted to the production of different bio-functional materials, such as biochar with a low pyrolysis temperature, refined charcoal with a high pyrolysis temperature and $\mathrm{AC}$ with various carbonization and activation temperatures. According to the difference in porosity, specific surface areas and adsorption characteristics, multi-utilization for the application of biochar, charcoal and $\mathrm{AC}$ was considered from AFPW.

Figure 1 depicts a flow chart of this paper. The bio-functional materials prepared from AFPW are illustrated under three subjects: (1) the prepared biochar as a substrate 
in a portion of cultural media with $\mathrm{C}$-rich residues, organic substances and mineral elements; (2) the refined charcoal as a food moisture-proof adsorbent with the ability for absorption and high specific surface areas and (3) the prepared $\mathrm{AC}$ with better characteristics of adsorption/desorption as a water purification material. These hopefully increase the value-added, resource-utilized and/or ability-evaluated for AFPW, when they are applied to the safety of human health, the function of life and the sustainable use of the ecosystem. Furthermore, for the product life cycle assessment, these bio-functional materials are needed to evaluate their carbon footprint, carbon sequestration and carbon cycle in the future.

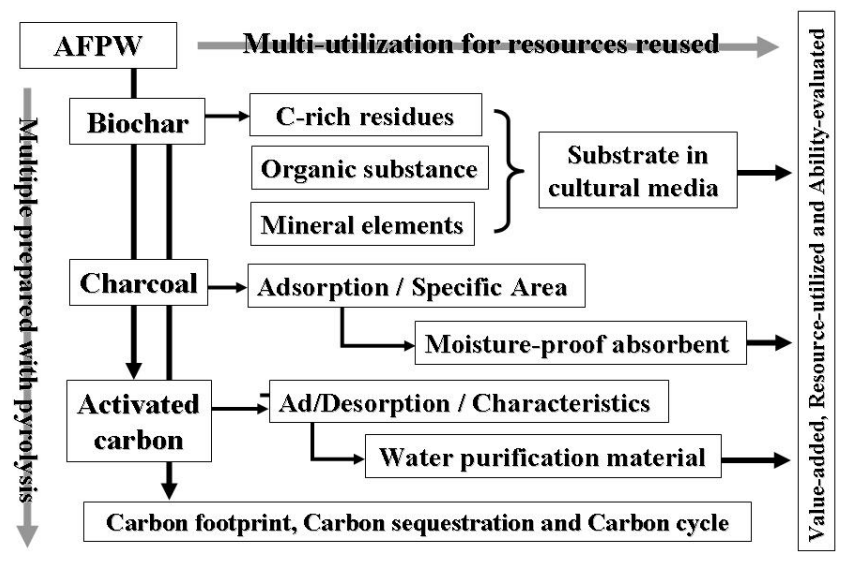

Figure 1. A flow chart of bio-functional materials preparing from agricultural/forestry processed wastes (AFPW)

\section{Biochar as Part of Cultural Media}

The advantage of the addition of biochar to the soil is that it has the ability to retain nutrients, high stability against decay and the ability to remove carbon dioxide from the atmosphere and revitalize degraded ground [7]. This is because biochar is a carbon rich, about $65-90 \%$, and porous substance with oxygen functional groups and/or aromatic surfaces $[8,9]$. Using biochar as a portion of cultural media, such as vegetable plug seedlings, assists in many ways including preservation of moisture and fertility, availability of oxygen to expand the roots, etc. [7, 10-12].

The first section of this paper describes biochar that was prepared from AFPW, including sorghum distillery residue (SDR), cultivation bag waste (CBW), Japanese cedar sawdust (JCS) and pulp sludge (PS), to be used as a cultural media substrate. Digital images of SDR, CBW, JSC and PS, as well as each prepared biochar are shown in Figure 2. Huang [6] reported that the carbonization temperature had a strong influence on both physical and chemical characteristics of various biochars. The yield and $\mathrm{C}, \mathrm{N}$ and $\mathrm{H}$ contents of biochar specimens were $31.02-89.02 \%, 18.94-85.79 \%$, $0.80-5.95 \%$ and $0.06-4.66 \%$. The $\mathrm{C}$ and $\mathrm{H}$ contents of JCS biochar were the highest followed by SDR biochar, but the $\mathrm{N}$ content of SDR biochar was higher than the others. The $\mathrm{pH}$ value, iodine value and electrical conductivity of 4 types of biochar were $6.46-11.73,42.29-341.42 \mathrm{mg} / \mathrm{g}$ and $0.07-3.44$ $\mathrm{ds} / \mathrm{m}$. The water absorption in the SDR and JCS biochars were increased with the increase in carbonization temperature. The average pore diameter ranged from 3.88 to $28.96 \mathrm{~nm}$ belonging mostly to mesoporous structures. These prepared biochars, therefore, represent a potential material for cultural media substrate.

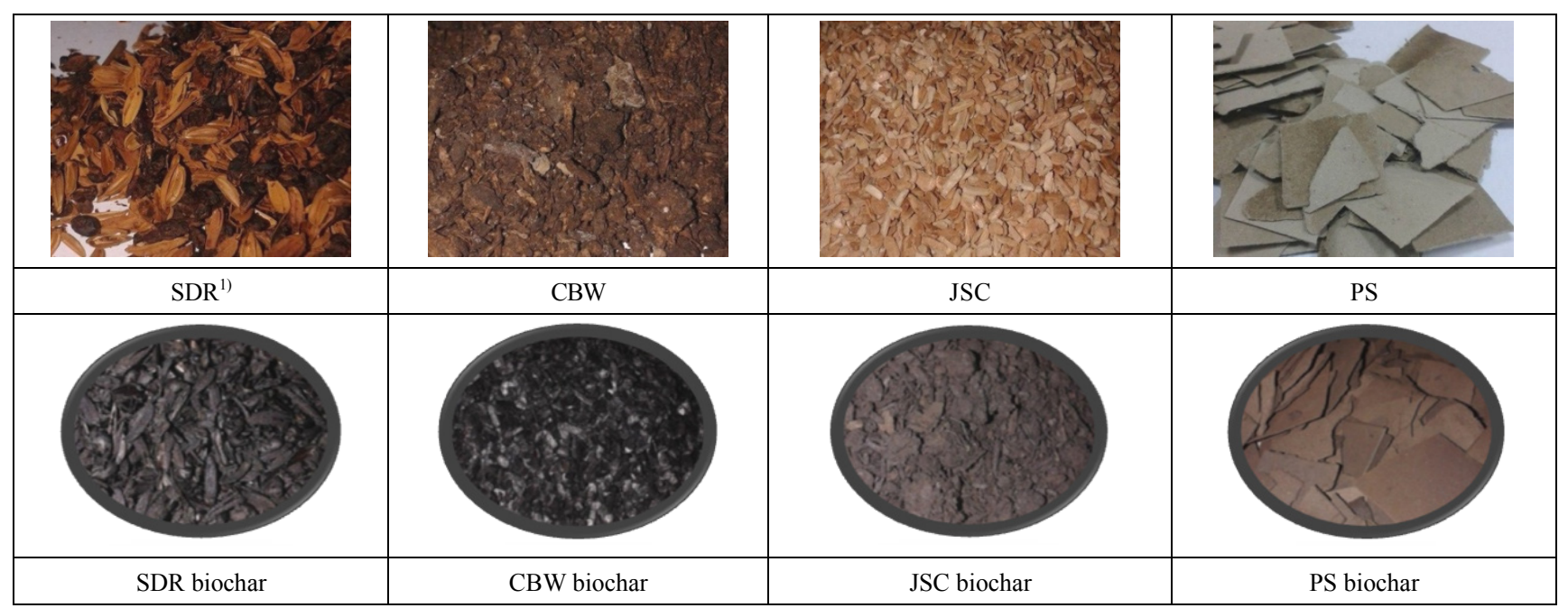

Notes SDR: sorghum distillery residue; CBW: cultivation bag waste; JSC: Japanese cedar sawdust (JSC); PS: pulp sludge

Figure 2. Digital images of SDR, CBW, JSC and PS, and resulting products - biochar 
Table 1 shows the physical properties of cultural media, including perlite and prepared biochar, with different carbonization temperatures mixed with a peat medium. The air-filled porosity (AFP) of the commercial perlite + peat (control group) was $9.03 \%$ and those for 200 to $450+$ peat (test groups) were from 11.11 to $12.75 \%$, which was significantly different from Duncan's multiple range tests. The container capacity (CC) of the control group was $65.88 \%$ and capacities for the test groups were from 61.87 to $62.94 \%$. The $\mathrm{CC}$ of the peat containing biochar carbonized at six different temperatures was higher than that of the control group. The total porosity (TP) of the control group was $72.74 \%$ and those of the test groups were from 71.08 to $73.44 \%$. It was observed that the TP of the six types of test groups was about the same as that of the control group (Table 1). The above results indicate that the cultural media are close to the ideal media in service [13-15]. In addition, the bulk density (BD) of the control group was $0.13 \mathrm{~g} / \mathrm{cm}^{3}$ and those of all test groups were from 0.12 to $0.14 \mathrm{~g} / \mathrm{cm}^{3}$. Therefore, the BD of the cultural media was lower than the ideal range of $\mathrm{BD}\left(0.3\right.$ to $\left.0.7 \mathrm{~g} / \mathrm{cm}^{3}\right)$ [16]. Both of them are classified as lightweight media. The results suggest that the physical properties of the six types of test groups are close to those of the control group.

The following results are not shown in this paper. The cucumber (Cucumis sativus L.) plug seedlings indicated that for the 28th day the dry weight and fresh weight with perlite in the media were $4.510 \mathrm{~g}$ and $0.467 \mathrm{~g}$; the SDR biochar values at $450^{\circ} \mathrm{C}$ carbonization temperature were $4.203 \mathrm{~g}$ and $0.484 \mathrm{~g}$; the CWB biochar values at $450^{\circ} \mathrm{C}$ were $4.023 \mathrm{~g}$ and $0.421 \mathrm{~g}$; the JCS biochar values were $4.361 \mathrm{~g}$ and $0.462 \mathrm{~g}$ and the PS biochar values were $4.311 \mathrm{~g}$ and $0.480 \mathrm{~g}$. Table 2 illustrates the seedling index for cucumbers in various cultural media during the 7 to 28 -day nursery growth period. The seedling indexes of the control group and test groups all increased as time went by. According to Duncan's multiple range tests, on the $7^{\text {th }}, 14^{\text {th }}, 21^{\text {st }}$ and $28^{\text {th }}$ day, the seedling index of the cultural medium with perlite was smaller than that of the SDR biochar at $450^{\circ} \mathrm{C}$ carbonization temperature. The seedling index of the SDR biochar at $450^{\circ} \mathrm{C}$ was the highest one with significant differences to perlite in the media and the other test groups. Moreover, Huang [6] reported that during the plug seedling period, the cation exchange capacity (CEC) of the media with biochar at $450^{\circ} \mathrm{C}$ was higher than that of the media with perlite.

The above results suggest that AFPW biochar as the cultural media substrate was able to contribute to quality growth of the vegetable plug seedlings. Among all, the seedling index for cultural media with SDR biochar at $450^{\circ} \mathrm{C}$ carbonization temperature as the substrate at a $15 \%$ volume was better than the media with perlite and the others that could obtain better quality growth of vegetable plug seedlings.

Table 1. Physical property of cultural media with SDR biochar ${ }^{1)}$

\begin{tabular}{|c|c|c|c|c|}
\hline Cultural media $^{2)}$ & $\mathrm{AFP}^{3)}(\%)$ & $\mathrm{CC}(\%)$ & TP $(\%)$ & $\mathrm{BD}\left(\mathrm{g} / \mathrm{cm}^{3}\right)$ \\
\hline Perlite + peat $^{4)}$ & $9.03(2.03)^{\mathrm{a} 5)}$ & $65.88(3.55)^{\mathrm{c}}$ & $72.74(1.33)^{b}$ & $0.13(0.01)^{\mathrm{bc}}$ \\
\hline $200^{6}+$ peat & $11.11(0.14)^{\mathrm{b}}$ & $61.87(2.13)^{\mathrm{a}}$ & $71.08(1.55)^{\mathrm{a}}$ & $0.12(0.01)^{\mathrm{b}}$ \\
\hline $250+$ peat & $12.14(2.40)^{\mathrm{c}}$ & $62.94(3.64)^{\mathrm{b}}$ & $72.09(1.37)^{\mathrm{b}}$ & $0.12(0.01)^{\mathrm{b}}$ \\
\hline $300+$ peat & $12.30(3.26)^{\mathrm{c}}$ & $62.86(1.71)^{\mathrm{b}}$ & $72.66(1.54)^{\mathrm{b}}$ & $0.13(0.01)^{\mathrm{bc}}$ \\
\hline $350+$ peat & $12.21(1.42)^{\mathrm{c}}$ & $62.54(3.70)^{\mathrm{b}}$ & $72.84(1.65)^{b}$ & $0.13(0.01)^{\mathrm{bc}}$ \\
\hline $400+$ peat & $12.75(0.68)^{\mathrm{c}}$ & $62.23(5.10)^{\mathrm{b}}$ & $73.44(2.09)^{\mathrm{c}}$ & $0.14(0.01)^{\mathrm{c}}$ \\
\hline $450+$ peat & $12.19(0.54)^{\mathrm{c}}$ & $62.74(4.31)^{\mathrm{b}}$ & $73.12(2.10)^{\mathrm{c}}$ & $0.14(0.01)^{\mathrm{c}}$ \\
\hline \multicolumn{5}{|c|}{$\begin{array}{l}{ }^{1)} \text { SDR biochar: sorghum distillery residue biochar; } \\
\text { 2) Cultural media: substrate: peat = 15: } 85 \text { (v/v \%); } \\
\text { 3) AFP: air-filled porosity; CC: container capacity; TP: total porosity; BD: bulk density; } \\
\text { (4) control group; } \\
\text { different substrate at the same peat to control group; } \\
\text { () SDR biochar prepared with the carbonization temperature to as cultural media substrate. }\end{array}$} \\
\hline
\end{tabular}

Table 2. Seedling index of cucumber for cultural media with perlite and SDR biochar during 28 nursery growth period

\begin{tabular}{|c|c|c|c|c|}
\hline \multirow{2}{*}{ Cultural media $^{1)}$} & \multicolumn{4}{|c|}{ Days of seedling growth (in days) } \\
\cline { 2 - 5 } & 7 & 14 & 21 & 28 \\
\hline Perlite + peat $^{2)}$ & $0.022(0.003)^{\mathrm{aA3})}$ & $0.099(0.013)^{\mathrm{aA}}$ & $0.213(0.038)^{\mathrm{abA}}$ & $0.279(0.041)^{\mathrm{aA}}$ \\
\hline $200^{4)}+$ peat & $0.038(0.004)^{\mathrm{cd}}$ & $0.110(0.013)^{\mathrm{a}}$ & $0.189(0.058)^{\mathrm{a}}$ & $0.267(0.079)^{\mathrm{a}}$ \\
\hline $250+$ peat & $0.032(0.004)^{\mathrm{b}}$ & $0.097(0.017)^{\mathrm{a}}$ & $0.204(0.013)^{\mathrm{ab}}$ & $0.286(0.052)^{\mathrm{a}}$ \\
\hline $300+$ peat & $0.035(0.004)^{\mathrm{bc}}$ & $0.108(0.015)^{\mathrm{a}}$ & $0.202(0.024)^{\mathrm{ab}}$ & $0.351(0.035)^{\mathrm{a}}$ \\
\hline $350+$ peat & $0.034(0.003)^{\mathrm{bc}}$ & $0.107(0.014)^{\mathrm{a}}$ & $0.225(0.012)^{\mathrm{ab}}$ & $0.295(0.048)^{\mathrm{a}}$ \\
\hline $400+$ peat & $0.038(0.003)^{\mathrm{cd}}$ & $0.118(0.020)^{\mathrm{ab}}$ & $0.231(0.029)^{\mathrm{ab}}$ & $0.347(0.087)^{\mathrm{a}}$ \\
\hline $450+$ peat & $0.040(0.007)^{\mathrm{dB}}$ & $0.134(0.014)^{\mathrm{bB}}$ & $0.244(0.019)^{\mathrm{bB}}$ & $0.338(0.094)^{\mathrm{aB}}$ \\
\hline
\end{tabular}

${ }^{1), 2)}$ and $^{4)}$ are the same as Table $1^{2), 4)}$ and ${ }^{6)}$;

${ }^{3)}$ Mean (standard deviation) with the different superscripts are significantly different $(\rho<0.05)$ by Duncan's multiple range tests. The lower alphabets express the different substrate at the same peat to control group. The upper alphabets express SDR biochar at $450{ }^{\circ} \mathrm{C}$ of carbonization temperature with peat to control group. 


\section{Refined Charcoal as Food Moisture-proof Adsorbent}

Charcoal is a porous material with a high specific surface area that has many functions, such as indoor deodorization, humidity control, water quality improvement and air purification [17], and can be added as a pigment in food [18, 19]. After being refined by activation, charcoal becomes AC that still retains the charcoal's characteristics [20]. The high specific surface area and total pore volume of AC are greater than those of charcoal [21] and can be applied for gaseous and liquid adsorption [22]. However, the charcoal and AC raise a profound question as to whether or not residue in vivo causes any harm by inducing cell lesions or carcinogens, when they are considered as a food moisture-proof absorbent or pigment ingredients. The second section of this paper addresses the moisture absorption and preliminary safety of AC refined from Makino bamboo, Moso bamboo and Japanese cedar charcoals with $\mathrm{CO}_{2}$ at different activation temperatures and times [20].

The hygroscopicity for charcoal and $\mathrm{AC}$ at both relative humidities (RH) of 40 and $90 \%$ is shown in Table 3 . No matter what the $\mathrm{RH}$ was, the maximum weight percent of the AC was better than that of charcoal. According to Duncan's analysis, at 40 and $90 \%$ RH the maximum weight percent of AC and charcoal is obviously different. The maximum weight percents of Makino bamboo, Moso bamboo and Japanese cedar AC at 40\% RH were $12.1-30.6 \%, 11.6-23.8 \%$ and $10.1-16.8 \%$, higher than that of silica gel at $11.07 \%$. For a $90 \% \mathrm{RH}$, the maximum weight percent of $\mathrm{AC}$ was 15.2-45.1\%, higher than that (9.9-13.3\%) of all charcoals. The highest maximum weight percent $(45.1 \%)$ was found to be for Makino bamboo AC with $\mathrm{CO}_{2}$ at $900^{\circ} \mathrm{C}$ activation temperature for $150 \mathrm{~min}$ which was higher than for silica gel (37.2\%); the lowest (15.2\%) was Makino bamboo $\mathrm{AC}$ with $\mathrm{CO}_{2}$ at $800^{\circ} \mathrm{C}$ for 90 min. This indicates that the increase in the moisture adsorption is based on the increase of both activation temperature and time. Moreover, no matter what kind of $\mathrm{AC}$ is used, the higher hygroscopic ability is affected by the activation temperature and time, and the influence of the activation temperature is greater than that of the activation time $[23,24]$.

Table 3. Maximum percent weight of charcoals, activated carbons and silica gel in high/low relative humidity conditions at either 90 or $40 \%$ with a constant temperature at $25^{\circ} \mathrm{C}$

\begin{tabular}{|c|c|c|c|c|}
\hline \multirow{2}{*}{ Precursor } & \multicolumn{2}{|c|}{ Activation } & \multicolumn{2}{|c|}{ Maximum percent weight (\%) } \\
\hline & Temperature $\left({ }^{\circ} \mathrm{C}\right)$ & Time (min) & $40 \% \mathrm{RH}$ & $90 \% \mathrm{RH}$ \\
\hline \multirow{7}{*}{$\begin{array}{l}\text { Makino bamboo } \\
\text { charcoal }\end{array}$} & Control & $-1)$ & $9.2(0.48)^{\mathrm{aA} 2)}$ & $11.3(0.63)^{\mathrm{aA}}$ \\
\hline & \multirow{3}{*}{800} & 90 & $12.1(0.24)^{\mathrm{b}}$ & $15.2(0.93)^{\mathrm{b}}$ \\
\hline & & 120 & $13.0(0.24)^{\mathrm{c}}$ & $17.1(0.78)^{\mathrm{c}}$ \\
\hline & & 150 & $13.8(0.51)^{\mathrm{d}}$ & $18.2(0.75)^{\mathrm{c}}$ \\
\hline & \multirow{3}{*}{900} & 90 & $21.3(0.78)^{\mathrm{B}}$ & $28.5(0.65)^{\mathrm{B}}$ \\
\hline & & 120 & $24.3(0.94)^{\mathrm{C}}$ & $34.6(1.06)^{\mathrm{C}}$ \\
\hline & & 150 & $30.6(2.96)^{\mathrm{D}}$ & $45.1(0.97)^{\mathrm{D}}$ \\
\hline \multirow{7}{*}{$\begin{array}{l}\text { Moso bamboo } \\
\text { charcoal }\end{array}$} & Control & - & $6.7(031)^{\mathrm{aA}}$ & $9.9(0.26)^{\mathrm{aA}}$ \\
\hline & \multirow{3}{*}{800} & 90 & $11.6(0.28)^{b}$ & $15.6(0.49)^{\mathrm{b}}$ \\
\hline & & 120 & $12.5(0.25)^{\mathrm{c}}$ & $17.3(0.94)^{\mathrm{c}}$ \\
\hline & & 150 & $13.1(0.29)^{\mathrm{d}}$ & $17.6(0.41)^{\mathrm{c}}$ \\
\hline & \multirow{3}{*}{900} & 90 & $20.0(1.25)^{\mathrm{B}}$ & $29.1(0.71)^{\mathrm{B}}$ \\
\hline & & 120 & $22.1(1.34)^{\mathrm{C}}$ & $29.9(1.10)^{\mathrm{B}}$ \\
\hline & & 150 & $23.8(1.09)^{\mathrm{D}}$ & $40.3(0.75)^{\mathrm{C}}$ \\
\hline \multirow{7}{*}{$\begin{array}{l}\text { Japanese cedar } \\
\text { charcoal }\end{array}$} & Control & - & $9.5(0.52)^{\mathrm{aA}}$ & $13.3(0.45)^{\mathrm{aA}}$ \\
\hline & \multirow{3}{*}{800} & 90 & $10.1(0.64)^{b}$ & $17.4(1.03)^{\mathrm{b}}$ \\
\hline & & 120 & $10.5(1.61)^{\mathrm{c}}$ & $17.9(2.28)^{\mathrm{b}}$ \\
\hline & & 150 & $10.7(0.57)^{\mathrm{d}}$ & $18.7(1.02)^{\mathrm{b}}$ \\
\hline & \multirow{3}{*}{900} & 90 & $15.1(1.08)^{\mathrm{B}}$ & $32.7(1.82)^{\mathrm{B}}$ \\
\hline & & 120 & $16.1(1.02)^{\mathrm{C}}$ & $35.7(3.37)^{\mathrm{B}}$ \\
\hline & & 150 & $16.8(1.40)^{\mathrm{D}}$ & $33.4(2.10)^{\mathrm{B}}$ \\
\hline Silica gel & - & - & $11.7(0.10)$ & $37.2(0.17)$ \\
\hline
\end{tabular}

1) - : Non condition;

${ }^{2)}$ Mean (standard deviation) separation within columns to control group (Control) by Duncan's multiple range tests at $5 \%$ significant level. Alphabets express the different activation time at the same activation temperature to Control. 
The water activity (Aw) indicates the amount of water in the total water content available to micro-organisms. Each of the species of micro-organisms has its own minimum Aw. The growth of micro-organisms is no longer possible when the Aw is below 0.65-0.95 [25]. After the charcoals were refined by using physical activation, the Aw of the AC decreased and was lower than the Aw for micro-organism growth. The Aw values of charcoals and $\mathrm{AC}$ were $0.56-0.58$ and $0.45-0.46$, respectively (results not shown in this paper). The heavy metal content (as $\mathrm{Pb}$ ppm base) of charcoal and AC were below $40 \mathrm{ppm}$ (results not shown in this paper) and met the Sanitation Standard for Edible Natural Colorants, Food Sanitation Standards. For the Ames test, none of the charcoal or prepared AC had toxicity or mutagenicity toward Salmonella typhimurium TA98 and TA100 with or without S9 (results not shown in this paper). It is suggested that since the preliminary safety evaluation shows no toxicity and mutagenicity, charcoal and AC can not only be considered to be safe pigment materials for food, but also can be used as natural moisture-proof materials due to their low AW and good adsorption.

\section{Activated Carbon as Water Purification Material}

$\mathrm{AC}$ is a porous adsorbing material with a nonpolar surface and is effective in adsorbing organic matter from water solution [26-28]. It has stable chemical properties and is resistant to acid, alkali, high temperatures and high pressure, and is extensively applicable to the drinking water purification process [29]. SDR, one residual product brewed from sorghum liquor, generally is part of fermentation wastes in the food industry. According to the Environmental Protection Administration, Executive Yuan in Taiwan [30], the annual output for SDR is about 131000 MT, which is in accordance with the statistics reported for industrial waste. For example, the daily output of SDR is about 300 tons in Kinmen County, one important production area for sorghum liquor in Taiwan, and this increases year by year [31]. SDR has not been developed nor has it become a highly value-added product, even though it has been researched in areas such as soil improvement and crop nutrition [32, 33], compost materials $[34,35]$, biotransformation using fungus [36], extraction of antioxidants [37, 38], functional application of extracts [39, 40], production of ethanol biomass [31] and feed improvement [41-44]. SDR is also a fibrous material and/or carbonaceous matter, which can become an $\mathrm{AC}$ by the use of a suitable pyrolysis and/or activation method. SDR can be prepared into SDRAC with multiple mesopores [45]. The following study reports on sorghum distillery residue activated carbon (SDRAC) being prepared by physical activation to evaluate its application to water purification, as well as the preliminary safety of water quality before and after purification [46]. The photos and microscope observations for the SDR and the SDRAC specimens are shown in Fig. 3. The 500 times SEM micrograph of SDR indicated that there was no pore with a rugged surface, and the image of SDRAC showed the presence of uneven honeycomb-like groups of pores on the surface.

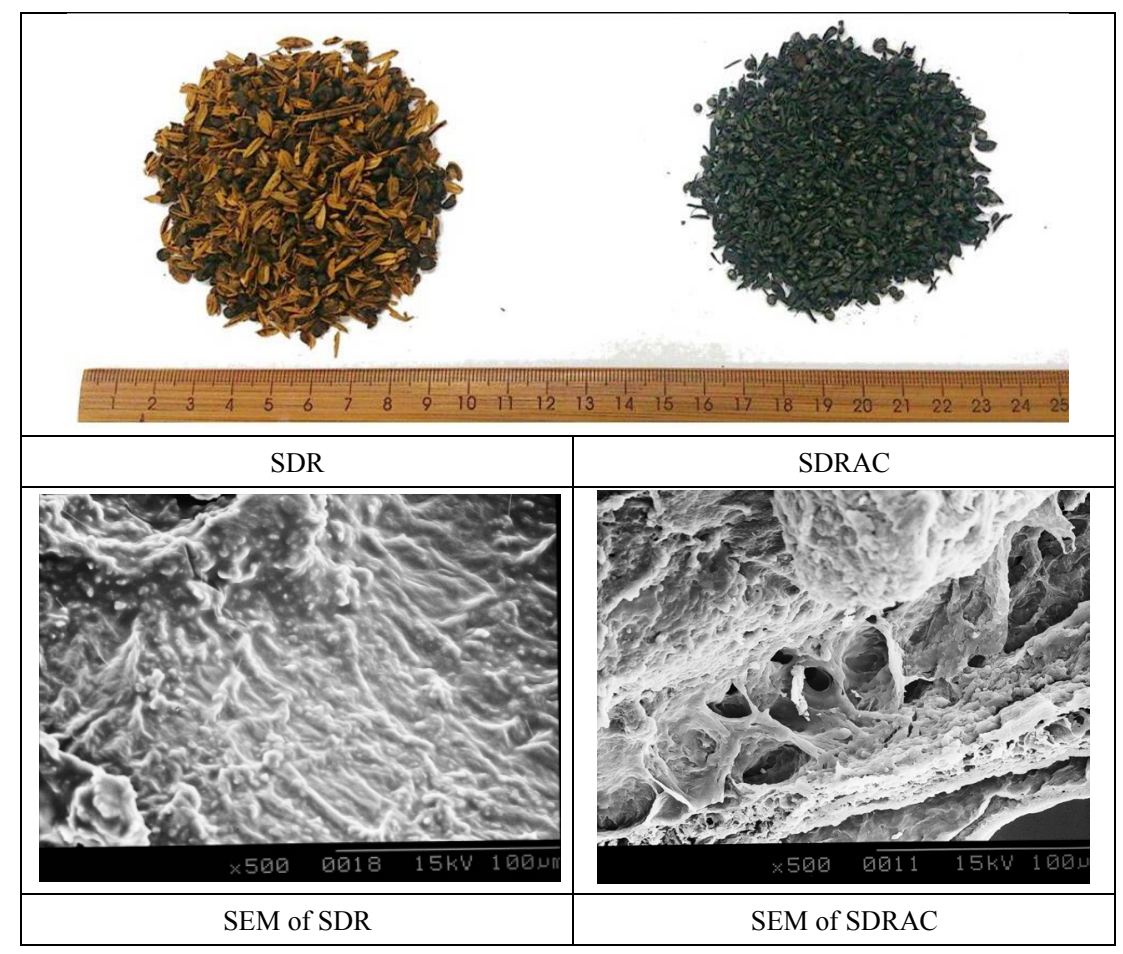

Note: SDRAC: sorghum distillery residue activated carbon

Figure 3. Photos and SEM (x 500) of SDR and SDRAC 
The two types of water purification methods were as follows: (1) standing method: the SDRAC and the water specimen were mixed at a weight ratio of $1: 10(\mathrm{wt} \%)$ and kept still for 30 and 60 min [47]; (2) filtration method: the SDRAC was placed in a glass funnel. The water specimen flowed from the top to the bottom under gravity and was controlled by a valve. The flow velocities were $10 \pm 2 \mathrm{~mL} / \mathrm{min}$ and $5 \pm 2 \mathrm{~mL} / \mathrm{min}$ [48], and the weight ratio of SDRAC to the water specimen was 1:10 (wt $\%)$ as well. The turbidity of the water specimen was determined by the ratio of the reference standard turbidity suspension of the water specimen to the intensity of the specific scattered light, and the unit used was Nephelometric Turbidity Unit (NTU) [49]. Table 4 shows the turbidity of the raw water and slow filter water purified by the filtration method with SDRAC. The raw water turbidity was 20.6 NTU, and the slow filter water was 1.34 NTU. The turbidity of the raw water was reduced to 2.80-1.73 NTU after filtration. The water turbidity was able to be removed by $86.4-91.6 \%$; the turbidity of slow filter water was removed by $7.4-58.9 \%$, i.e. $1.24-0.55$ NTU. It was indicated that the SDRAC was influenced by them when purifying water, and the water turbidity decreased as the flow velocity decreased. The water quality standard for drinking water specifies the turbidity as 2 NTU. It is suggested that the raw water specimen processed by SDRAC at a flow velocity of $5 \pm 2 \mathrm{~mL} / \mathrm{min}$ can reach the water quality standard for drinking water.

The following results are not shown in this paper. The $\mathrm{pH}$ value of water was increased by the SDRAC filtration or standing in the solution, and the $\mathrm{pH}$ value, after processing, was increased by 13.4-61.6\%. The total hardness of the raw water and slow filter water specimens processed by SDRAC was removed by $23.2-52.3 \%$, and the value was 55.6-88.6 $\mathrm{mg} / \mathrm{L}$. The nitrite nitrogen concentration could be reduced after processing by SDRAC. Table 5 shows the total bacterial count of raw water and slow filter water specimens, as filtered by the standing method with SDRAC. The total bacterial count for raw water was $1539 \mathrm{CFU} / \mathrm{mL}$. The total bacterial count decreased significantly after standing, and the total bacterial count in water was reduced by $99.5-99.9 \%$ after 30 and $60 \mathrm{~min}$ SDRAC standing, i.e. 1-5 CFU/mL. The total bacterial count was able to be reduced by more than $99 \%$, thus, conforming to the water quality standard for drinking water $(100 \mathrm{CFU} / \mathrm{mL})$. Uraki et al. [50] reported that the $\mathrm{AC}$ filtration and standing processes are effective methods to reduce the total bacterial count in water. The active mechanism operates when the strong alkaline solution condition is presented in AC to cause bacterial death and the bacteria are adsorbed in the $\mathrm{AC}$.

Table 4. Turbidity ${ }^{1)}$ of water specimen for raw water and slow filter water after processing by standing method with SDRAC ${ }^{2)}$ Unit: NTU

\begin{tabular}{|c|c|c|c|c|}
\hline Water specimen $^{3)}$ & Raw water $^{4)}$ & Percent removal (\%) & Slow filter water & Percent removal (\%) $^{4{ }^{4}}$ \\
\hline Blank $^{6)}$ & $20.60(1.84)^{\mathrm{b7}}$ & - & $1.34(0.39)^{\mathrm{b}}$ & - \\
\hline $\mathrm{T} 850-60-90-10 \mathrm{~mL} / \mathrm{min}^{8)}$ & $2.50(0.26)^{\mathrm{a}}$ & 87.8 & $1.11(0.24)^{\mathrm{b}}$ & 17.1 \\
\hline $\mathrm{T} 850-60-90-5 \mathrm{~mL} / \mathrm{min}$ & $1.73(0.16)^{\mathrm{a}}$ & 91.6 & $0.60(0.06)^{\mathrm{a}}$ & 55.2 \\
\hline $\mathrm{T} 800-60-90-10 \mathrm{~mL} / \mathrm{min}$ & $2.80(0.29)^{\mathrm{a}}$ & 86.4 & $1.24(0.26)^{\mathrm{b}}$ & 7.4 \\
\hline $\mathrm{T} 800-60-90-5 \mathrm{~mL} / \mathrm{min}$ & $1.96(0.03)^{\mathrm{a}}$ & 90.4 & $0.59(0.15)^{\mathrm{a}}$ & 55.9 \\
\hline $\mathrm{T} 800-60-120-10 \mathrm{~mL} / \mathrm{min}$ & $2.36(0.36)^{\mathrm{a}}$ & 88.5 & $0.99(0.24)^{\mathrm{ab}}$ & 26.1 \\
\hline $\mathrm{T} 800-60-120-5 \mathrm{~mL} / \mathrm{min}$ & $1.90(0.14)^{\mathrm{a}}$ & 90.7 & $0.61(0.14)^{\mathrm{a}}$ & 54.4 \\
\hline $\mathrm{T} 800-60-150-10 \mathrm{~mL} / \mathrm{min}$ & $2.36(0.28)^{\mathrm{a}}$ & 88.5 & $0.94(0.15)^{\mathrm{ab}}$ & 29.8 \\
\hline $\mathrm{T} 800-60-150-5 \mathrm{~mL} / \mathrm{min}$ & $1.84(0.06)^{\mathrm{a}}$ & 91.0 & $0.55(0.04)^{\mathrm{a}}$ & 58.9 \\
\hline
\end{tabular}

1) Turbidity of water quality standard for drinking water source is no standard; Turbidity of water quality standard for drinking water is 2 NTU [49];

2) SDRAC: see the Figure 3;

3) Water specimen was processed by method of water purification with different prepared SDRAC;

4) The raw water and the slow filter water were obtained on May 27, 2014;

${ }^{5)}$ Percent removal $(\%)=[($ turbidity of blank - turbidity of water specimen after processing with SDRAC) / turbidity of blank $] * 100$;

${ }^{6}$ ) Blank: water specimen is raw water or slow filter water that unprocessed with any SDRAC;

${ }^{7)}$ Mean (standard deviation) with the different superscripts are significantly different $(\rho<0.05)$ by Duncan's multiple range tests;

${ }^{8)} \mathrm{T}$ (Activation temperature) - Activation duration - Flow rate - Time of flow velocity

Table 5. Total bacterial count ${ }^{1)}$ of water specimen for raw water and slow filter water after processing by standing method with SDRAC ${ }^{2)}$ Unit: mg/L

\begin{tabular}{|c|c|c|c|c|}
\hline Water specimen $^{3)}$ & Raw water ${ }^{4)}$ & Percent removal (\%) ${ }^{5)}$ & slow filter water ${ }^{4)}$ & Percent removal (\%) \\
\hline Blank $^{6}$ & $1539(66.00)^{\mathrm{b} 7)}$ & - & $1025(104.00)^{\mathrm{b}}$ & - \\
\hline T850-60-90-30min ${ }^{8)}$ & $3(0.82)^{\mathrm{a}}$ & 99.8 & $1(0.00)^{\mathrm{a}}$ & 99.9 \\
\hline T850-60- 90-60min & $4(1.70)^{\mathrm{a}}$ & 99.7 & $5(1.63)^{\mathrm{a}}$ & 99.5 \\
\hline T800-60- 90- 30min & $1(0.00)^{\mathrm{a}}$ & 99.9 & $1(0.47)^{\mathrm{a}}$ & 99.9 \\
\hline T800-60-90-60min & $4(2.16)^{\mathrm{a}}$ & 99.7 & $2(0.82)^{\mathrm{a}}$ & 99.8 \\
\hline T800-60-120-30min & $2(0.47)^{\mathrm{a}}$ & 99.8 & $1(0.47)^{\mathrm{a}}$ & 99.9 \\
\hline $\mathrm{T} 800-60-120-60 \mathrm{~min}$ & $4(1.63)^{\mathrm{a}}$ & 99.7 & $5(1.63)^{\mathrm{a}}$ & 99.5 \\
\hline $\mathrm{T} 800-60-150-30 \mathrm{~min}$ & $1(0.00)^{\mathrm{a}}$ & 99.9 & $1(0.47)^{\mathrm{a}}$ & 99.9 \\
\hline T800-60-150-60min & $2(0.88)^{\mathrm{a}}$ & 99.8 & $3(2.16)^{\mathrm{a}}$ & 99.7 \\
\hline
\end{tabular}

1) Total bacterial count of water quality standard for drinking water source is no standard; Total bacterial count of water quality standard for drinking water is $100 \mathrm{mg} / \mathrm{L}$ [49];

${ }^{2)}$ : see the Figure $3 ;{ }^{3), 4), 6), 7) \text { and } 8)}$ see Table 4 ;

${ }^{5)}$ Percent removal $(\%)=[($ total bacterial count of blank - total bacterial count of water specimen after processing with SDRAC) / total bacterial count of blank] * 100 
The accepted concentration of coliform according to the water quality standard for drinking water sources is 20 $\mathrm{CFU} / \mathrm{mL}$, and the accepted concentration for drinking water is $0.06 \mathrm{CFU} / \mathrm{mL}[49,51]$. The filtrate of raw water, slow filter water filtered by SDRAC, and both standing and filtration methods were all below $1 \mathrm{CFU} / \mathrm{mL}$ (results not shown in this paper) in Taiwan. Besides, the bacterial survival rate of cytotoxicity testing for water specimens before and after purification was higher than $80 \%$ of the control specimen (Blank) and test groups; meaning there was no cytotoxicity. The mutagenicity results show that spontaneous revertants did not occur more than twice; thus, there was no mutagenicity (results not shown in this paper). The water processed by SDRAC meets water quality standards for drinking water, and the preliminary safety of SDRAC can be guaranteed by the Ames Tests. Therefore, SDR may be used to prepare AC, which can be prepared into SDRAC, and can be as the functional material for water purification.

\section{Conclusions}

AFPW was used for preparing biochar as the substrate of functional cultural media in plug seedling growth. It was feasible to apply biochar in quality growth of vegetable plug seedlings. Among all those tested, the seedling index for the cultural media with SDR biochar with a $450^{\circ} \mathrm{C}$ carbonization temperature substrate at $15 \%$ volume was better than those of the media with the perlite and the others demonstrated by better quality growth of the vegetable plug seedlings. The study also used one of AFPWs - SDR as the precursor to prepare SDRAC, using the method of physics activation with steam, to as the purification materials for evaluating the preliminary safety of water quality before and after purification. The water treated by SDRAC had no cytotoxicity or mutagenicity. Turbidity, total hardness, nitrite nitrogen, total bacterial count and coliform of the water purified prepared with SDRAC met the quality standards for drinking water in Taiwan. Besides, refined charcoal with better absorption and higher specific surface area is expected to be similar to the materials of edible natural colorants and/or natural moisture-proof adsorbents, because its Aw ranges from 0.45 to 0.46 . The heavy metal content in the $\mathrm{Pb}$ ppm base of refined charcoal was below $40 \mathrm{ppm}$. This meets the Sanitation Standard of Edible Natural Colorants from the announcement by the Department of Health's Executive Yuan, in Taiwan. The preliminary safety evaluation, using the Ames test for refined charcoal, had no cytotoxicity and mutagenicity as well. Therefore, the above biochar, refined charcoal and AC from AFPW concerned with the concept of multi-utilization with pyrolysis can be a reference for the use of bio-functional materials to attain the sustainable reuse of resources.

\section{Acknowledgements}

The authors are grateful to the LUH YIH ENVIRONMENT CO., LTD in Taiwan for materials and financial support. And we also offer our sincere appreciation to the National Science Council through Grant No. NSC 99-2221-E-415 -002 for financial support.

\section{REFERENCES}

[1] IPCC, Third Report of Green House Effect on the Earth-Climate Change 2001. Chuo Houki Press, 2002.

[2] W. A. W. A. K. Ghani, A. Mohd, G. Silva, R. T. Bachmannd, Y. H. Taufiq-Yap, U. Rashidf, A. Al-Muhtaseb. Biochar production from waste rubber-wood-sawdust and its potential use in $\mathrm{C}$ sequestration: Chemical and physical characterization, Industrial Crops and Products, Vol 44 18-24, 2013.

[3] K. H. Kim, J. Y. Kim, T. S. Cho, J. W. Choi. Influence of pyrolysis temperature on physicochemical properties of biochar obtained from the fast pyrolysis of pitch pine (Pinus rigida). Bioresour, Technol. Vol 118, 158-162, 2012.

[4] D. Kolodynska, R. Wnetrzak, J. J. Leahy, M. H. B. Hayes, W. Kwapinski, Z. Hubicki. Kinetic and adsorptive characterization of biochar in metal ions removal. Chem. Eng. J., Vol 197, 295-305, 2012.

[5] M. Balat, G. Ayar. Biomass energy in the world, use of biomass and potential trends. Energy Sources, Vol 27 931-940, 2005.

[6] J. J. Huang. Physic-chemical properties of biochar prepared from agricultural/forestry processed wastes as cultural media substance and its application in quality growth of vegetable plug seedling. Master thesis, Chiayi, Taiwan, 2014.

[7] N. Z. Rebitanim, W. A. W. A. KarimGhani, N. Rebitanim, M. A. M. Salleh. Potential applications of wastes from energy generation particularly biochar in Malaysia. Renewable and Sustainable Energy Reviews, Vol 21 694-702, 2013.

[8] X. Y. Yu, G. G.Ying, R. S. Kookana. Reduced plant uptake of pesticides with biochar additions to soil. Chemosphere, Vol 76, 665-671, 2009.

[9] G. Shrestha, S. Traina, C. Swanston. Black carbon's properties and role in the environment: a comprehensive review. Sustainability, Vol 2, 294-320, 2010.

[10] H. C. Lin, Y. D Wu, C. W. Peng, G. S. Hwang, W. R. Kuo. Application of Moso bamboo charcoal cultural media to vegetable plug seedlings. Forest Productions Industries, Vol 20 No. 2 165-174, 2010.

[11] H. C. Lin, Y. Y. H. Huang, T. R. Tsai, C. W. Peng, G. S. Hwang, W. R. Kuo. Investigation of promoting growth of Tomato plug seedlings from Moso bamboo charcoal cultural media with bamboo vinegar. J. Agric For. (NCYU), Vol 8 No. 2 58-72, 2010.

[12] H. M. Ho, W. R. Kuo, W. Peng, G. S. Hwang, H. C. Lin. Investigation of yield and seedling growth of cabbage from cultural media with Moso bamboo charcoal. J. Agric For. 
(NCYU), Vol 10 No. 1 43-60, 2013.

[13] S. R. Chang. Study on Compost of golden mushroom wastes as cultural media. Master thesis, Tainan, Taichung, 1996.

[14] Y. K. Xue. Effect of physical/chemical characteristics to cabbage and tomato plug seedlings. Master thesis, Taichung, 2000.

[15] K. T. Yang. Physical properties of spheric media with different size and water holding capacity. Master thesis, Tainan, Taiwan, 2008.

[16] A. Garcia-Gomez, M. P. Bernal, A. Roig: Biores. Growth of ornamental plants in two composts prepared from agroindustrial waste. Biores. Technol., Vol 83 81-87, 2002.

[17] Y. Z. Lin, G. S. Hwang, I. S. Wang. Introduction to production and utilization of bamboo charcoal. Forest Tech. Report, Vol 10 No. 3 31, 2003.

[18] Department of Health's Executive. The Good Laboratory Practice for Nonclinical Laboratory Studies. Ministry of Health and Welfare, Executive Yuan, Taiwan,2006.

[19] B. S. Lee. Bamboo charcoal for inside body environmental protection. All Health, Vol 262 69-70, 2007.

[20] H. C. Lin, Y. C. Weng, G. S. Hwang, N. Fujimoto. Evaluation of adsorption and mutagenicity of activated carbons refined from charcoals. J. Faculty of Agriculture Kyushu University. Japan, Vol 59 No. 1 117-125, 2014.

[21] C. F. Chang, C. Y. Chang, W. T. Tsai. Effect of burn-off and activation temperature on preparation of activated carbon from corn cob agrowaste by $\mathrm{CO}_{2}$ and steam. J. Colloid Interface Sci., Vol 232 47, 2000.

[22] T. S. Liu. Preparation technology and applications of activated carbon. Indus. Inve. Tech., Vol 127 84-97, 1998.

[23] W. L. Wu, S. C. Wu, H. C. Lin. Investigation on water activity and absorption properties of activated carbons prepared from agricultural wastes using methods of physical activation with $\mathrm{CO}_{2}$ and steam. J Agric. For., Vol 7 No. 1-15, 2010.

[24] W. J. Huang, M. H. Duh, H. C. Lin. Investigation of absorption properties of activated carbon fibers prepared from Nadelholz/Laubholz pulp. J Agric. For., Vol 7 No. 1 16-31, 2010.

[25] W. T. Chang, M. T. Lee, M. M. Ru, G. W. Chang, S. T. Chen, R. S. Sun, E. H. Chen, S. W. Chen, C. S. Shiea, S. S. Lin, S. W. Lin. Food Chemistry. National Taiwan Edition, Taipei, 20-26, 2006.

[26] M. Tomaszewska, S. Mozia. 2002 Removal of organic matter from water by PAC/UF system. Water Research, Vol 36 No. 16 4137-4143, 2002.

[27] J. Przepiorski. Enhanced adsorption of phenol from water by ammonia-treated activated carbon. Hazardous Materials, Vol 135 No. 1 453-456, 2006.

[28] F. Villacan F., M. F. Pereira, J. M. Jose. Adsorption of simple aromatic compounds on activated carbon. Colloid and Interface Science, Vol 293 No.1 128-136, 2006.

[29] C. T. Jiang. Application principle and technology of activated carbon. Chemical Industry Publishing, 5-10, 2010.

[30] Environmental Protection Administration (EPA). Statistic report of industrial wastes. EPA, Executive Yuan, Taiwan,
2012.

[31] M. H. Su, W. S. Tzeng, Y. T. Shyu. An analysis of feasibility of bioethanol production from Taiwan sorghum. Bioresource technology, Vol 101 No.17 6669-6675, 2010.

[32] M. A.Bustamante, C. Paredes, M. C. Vargas-García, F. Suárez-Estrella, J. Moreno. Evolution of the pathogen content during co-composting of winery and distillery wastes. Bioresource technology, Vol 99 No. 15 7299-7306, 2008.

[33] R. P. Esperanza. César, S. Nicola, N. Rogelio, P. Alfredo. Humic Acid-like fractions in raw and vermicomposted winery and distillery wastes. Geoderma, Vol 139 No. 3 397-406, 2007.

[34] M. A. Bustamante, C. Paredes, R. Moral, J. Moralesb, A. M. Mayoral, R. Moral. Study of the composting process of winery and distillery wastes using multivariate techniques. Bioresource technology, Vol 100 No. 20 4766-4772, 2009.

[35] R. Paradelo, A. B. Moldes, M. T. Barral. Evolution of organic matter during the mesophilic composting of lignocellulosic winery wastes. J. of Environmental Management, Vol 116 No. 15 18-26, 2013.

[36] A. Perdih, A. Cimerman, J. Friedrich. Fungal bioconversion of fruit distillery waste. Enzyme and Microbial Technology, Vol 13 No. 10 848-852, 1991.

[37] T. I. Lafka, V. Sinanoglou, E. S. Lazos. On the extraction and antioxidant activity of phenolic compounds from winery wastes. Food chemistry, Vol 14 No. 3 1206-1214, 2007.

[38] B. Aliakbarian, A. Fathi, P. Perego, F. Dehghani. Extraction of antioxidants from winery wastes using subcritical water. J. of Supercritical Fluids, Vol 65 18-24, 2012.

[39] Y. Diao, W. P. Walawender, L. T. Fan. Activated carbons prepared from phosphoric acid activation of grain sorghum. Bioresource technology, Vol 81 No. 1 45-52, 2002.

[40] W. H. Lin. Proximate composition and functionality of water extract from Kinmen and Taiwan's sorghum distillery residue. Taichung, Master thesis, 2008.

[41] M. Lee, B. S. Pan. Effect of dietary sorghum distillery residue on hematological characteristics of cultured grey mullet (Mugil Cephalus) - An animal model for prescreening antioxidant and blood thinning activities. J. of Food Biochemistry, Vol 27 No. 1 1-18, 2003.

[42] S. Anandan, H. Zoltan, A. A. Khan, M. Blümmel. Feeding value of sweet sorghum bagasse and leaf residues after juice extraction for bio-ethanol production fed to sheep as complete rations in diverse physical forms. Animal Feed sci. and Tec., Vol 175 No. 3 131-136, 2012.

[43] T. T. Nguyen Thi. The in vitro and ex vivo digestibility of sorghum distillery residue fed to white shrimp (Litopenaeus vannamei). Keelung, Master thesis, 2012.

[44] Y. J. Wang. Identification of the lipid-soluble and water-soluble functional compounds of SDR and their cold-adaptation effect on tilapia. Keelung, Master thesis, 2012.

[45] H. C. Lin, J. S. Hu, W. J. Lee, C. W. Peng, Y. J. Lai, S. C. W, Noboru Fujimoto. Adsorption characteristics and pore structure of activated carbons prepared from sorghum distillery residue. J. Faculty of Agriculture Kyushu University. 
Japan, Vol 61 No. 1 173-182, 2015a.

[46] H. C. Lin, J. S. Hu, W. J. Lee, C. W. Peng, Y. J. Lai, S. C. W, Noboru Fujimoto. A study of sorghum distillery residue activated carbon for water purification. J. Faculty of Agriculture Kyushu University. Japan. (In publishing), 2015 b.

[47] K. C. Zhou, K. T. Lu. Improvement of drinking water qualities by using Moso bamboo activated carbon made from different activation temperatures. Quart. Journal Forest Research of Taiwan, Vol 32 No. 4 35-44, 2010.

[48] M. Ogawa, T. B. Bardant, Y. Sasaki, Y. Tamai, S. Tokura, Y. Uraki. Electricity-free production of activated carbon from biomass in borneo to improve water quality. Bio resources, Vol 7 No. 1 236-245, 2011.

[49] Environmental Protection Administration (EPA). Water Quality Standard for Drinking Water. EPA, Executive Yuan, Taiwan, 2013.

[50] Y. Uraki, Y. Tamai, M. Ogawa, S. Gaman, S. Tokura. Preparation of activated carbon from peat. Bio Resources, Vol 4 No. 1 205-213, 2008.

[51] Environmental Protection Administration (EPA). Water Quality Standard for Drinking Water Source. EPA, Executive Yuan, Taiwan, 1997. 